\title{
Eclecticism of rationalism in the pre- revolutionary architecture of civil public buildings in the city of Novocherkassk
}

\author{
Alexandra Lyudmirskaya* \\ Don State Technical University, 344010, Rostov-on-Don, Russia
}

\begin{abstract}
The article analyzes the little-studied eclectic tradition in the architecture of civil public buildings in Novocherkassk, the peculiarities of its manifestation in the diverse stylistic palette of the city, including neoGothic and Art Nouveau, touches on the specifics of the stylistic trends' manifestation in the rationalist architecture of the "masonry style", as well as the historical timing of changes in style in a temporary context.
\end{abstract}

\section{Introduction}

The pre-revolutionary history of the architecture of Novocherkassk goes back to the middle of 1804, when on August 23, Emperor Alexander 1 approved the founding of a new city on the Don, which was given the name "to be named New Cherkassk". The plan for the construction of a new regional center for the Donskoy army with wide avenues and boulevards was developed by engineer F.P. Devolan. On May 18, 1805, the solemn laying of New Cherkassk took place, "which until this day had existed for 235 years on the banks of the Don on an island from this place directly to the south, a distance of 20 versts under the name of Cherkassk." The transfer of the Don Cossacks capital to a new place was justified by long flooding of the city during spring floods, as well as by frequent fires, as a result of which a significant part of chaotically constructed wooden buildings without a general plan burned out [1].

The construction of New Cherkassk was very slow. The city, located on the top a steppe hill, was cut off from the water main of the Don, which made it difficult for its development and living.

For the stone construction of Novocherkassk in the period of the thirties and forties of the XIX century, the construction of buildings according to "exemplary" projects is characteristic. An example of this are the architectural buildings of the bishop's house and the buildings of the spiritual consistory (architect L. A. Ruska), erected on the eastern side of the cathedral square and reflecting the restrained Empire style in their architectural appearance [2].

From the middle of the 19th century, the construction and arrangement of the city proceeded at a faster pace and Novy Cherkassk began to acquire its architectural forms characteristic of the Don Cossacks capital. In the city, which was developing during this

\footnotetext{
* Corresponding author: a-lyudmirskaya@mail.ru
} 
period mainly as a military administrative center, capital brick civil construction of public buildings is being carried out, which entails the appearance of such stone buildings as guest houses, taverns, hotels, houses of generals and nobles, mansions, tenement houses, military and civil educational institutions, banks and exchanges, etc.

\section{Main Part}

The architecture of the newly emerging stone buildings largely reflects eclectic features corresponding to the classical style: the building of the "Military presence places" (1844), the stone house of the Society of Don Trade Cossacks (1846), the building of the Noble Assembly (1850). Rationalism manifests itself in the architectural buildings of the classical model, erected in most cases in the "masonry style" due to the fact that several brick factories already operated on the territory of the city, and the continental climate of the steppe region dictated the use of the most expedient plastic solutions in the facades of buildings with the aim of competent technology their construction and long-term operation.

In 1861, construction on the Grushevsko-Don railway through Novocherkassk began. In 1865 , the city receives its long-awaited water supply. These technical improvements bring Novy Cherkassk to the top ten large cities of Tsarist Russia and contribute to the further development of its industry and capital construction.

The architectural palette of the city of this period is in its own way monogamous and is expressed mainly in the imitation of classical reminiscences, manifested, for example, in the architecture of the military guardhouse building (1856), which resembles a small Greek temple.

In the Alexander Garden in 1863 (architect I.O. Valprede) the Ataman Palace was erected as the official residence of the Ataman of the Don Cossacks and Tsar's persons during the Tsar's visit to Novocherkassk [3]. The classical appearance of the palace with elements of the Empire and Neo-Renaissance reflects the typical features of 19th century mansions, which can combine both residential and public functions. The cast-iron balcony connecting the symmetrically located projections of the building is an excellent architectural and artistic example of combining parts into an integral composition using new technical means of time using artistic casting.

Shortly before the ataman house construction, in 1957, the academician of architecture I.O. Valprede is building stone shopping arcades on Platovsky Prospect, which complement the architectural ensemble of Alexandrovskaya Square, designed in a single classical style.

Despite the fact that Novy Cherkassk was a military administrative center and its main population was the military, who initially received literacy training mainly at home, the city gradually became a fairly large center of education. By the time of the opening of educational institutions, Novy Cherkassk was significantly ahead of Rostov-on-Don.

In 1853, the first secondary educational institution for girls was opened in the city - the Novocherkassk Mariinsky Institute for Noble Maidens, built in the neo-Renaissance style. In 1867 the Don Mariinsky Gymnasium began to operate, which in 1883 would receive a new building (architect A.A. Yashchenko), which had the style of the Palladian NeoRenaissance. In 1868, the Don Theological Seminary was opened, which in 1883 would be transferred to a new three-story building (architect A.A. Yashchenko), combining in its architectural appearance the symmetry of the classical style with the elements of Romanesque architecture, Byzantine triforic motifs and gable neo-Gothic completion central opening of the building, decorated with an arcature Gothic belt. In 1870, the Novocherkassk cadet school came into operation, the two-story building of which was designed in the classical style.

New Cherkassk was at that time the main city of the Don Diocese, therefore in 1889 the Diocesan School for Maiden was opened for the daughters of the Don clergy. In 1894, the 
school was transferred to a specially constructed building on Platovsky Avenue (architect P.S. Studenikin) [4]. The building of the Theological School occupied a large territory and had a symmetry of the plan; first level rustication; a huge two-level order of three paired columns with currency ends flanking the protruding projections of the building at the corners; elongated window openings with keeled cornice and pilasters; a complex profiled cornice, ending in the roof space with dormer windows in the form of gables. A huge threestorey building of red brick, which has a quarterly development, is made in the "masonry style" of neo-Russian eclecticism.

Another striking example, reflecting the rational neo-Russian tradition of Novocherkassk, is the building of the Theological School, built in the middle of the 19th century on Yermak Avenue for Major General Shushkov as a residential mansion in the Russian "masonry" style. Subsequently, it was acquired by the Diocesan administration and the School of Theology was located in it. By 1902, the central part of the building was rebuilt. On its second floor there was a house church in the name of the Intercession of the Mother of God, so the building acquired the completed church onion domes, which were lost after the October Revolution. But the general style of Russian architectural eclecticism in the form of paired keeled ends of windows and gables in the roofing part of the building remained.

In the last quarter of the 19th century, the traditional style of classical architectural forms, expressed in the symmetry of plans and facades, the rustication of buildings by levels, the use of order compositions in multi-column porticoes, framing window openings with triangular cornice, is reflected in civil educational institutions: the male classical gymnasium, which is 1876 receives a new building (architect A.A. Campioni); Ataman Technical School (architect K.F. Küntzel), which began operating in 1888.

For four years, from 1885 to 1889 in Novocherkassk, according to the project of architect. K.F. Kunzel, the construction of a complex of buildings of the Don Emperor Alexander III of the cadet corps was carried out. The facades and the plan of the complex were designed symmetrically, had a clear floor division, three risalits, ending with high roofs in the form of truncated pyramids that have not come down to us. The central risalit of the complex was accentuated by a balcony and a gable gothic finish on the third-floor level. The portal framing of windows in combination with pilasters and decorative details, tower endings of the central and corner projections, which have a Gothic pediment pattern, gave a special beauty and extraordinary originality to the complex. In the central section of the building there was a remote balcony on figured cast-iron racks and a porch of an original shape and decor. The exposed brickwork had clear ornamental constructions, reflecting the features of natural material, giving the complex a special expressiveness of the rationalist architecture of the "masonry style". The architect managed to create an original, brightly individual image of the complex in the ensemble, reflecting the taste of a Lutheran architect, enhanced by the experience of the provincial architect of Poltava [5].

The complex of the agricultural technical school in Persianovka, $20 \mathrm{~km}$ away, is a fantastic fabulous expression in the "masonry" architecture of the forms of neo-Gothic and Russian style, reflected in the national-romantic Art Nouveau. from Novocherkassk. For the complex construction, a large territory of the Steppe Reserve was allocated, and the hereditary nobleman of the Kingdom of Poland, professor A.I. Dietrich, who built more than one building in the cities of the Russian Empire. The structure had a complex, cruciform shape in plan with a pronounced central part with a semicircular tower and a dome. The multi-pitched roof with a comb, from the style of the "Russian ornamental" towers, ended along the flanks of the building with four-sided tents with triangular tongs with creeping arcature cutting into them, akin to Gothic tongs, but they are akin to Novgorod tongs of the 14th century. The elongated semicircular windows were crowned in relief with keeled cornice. The strict artistic structure of the architectural ensemble 
resembled a fabulous medieval castle. The completion of the complex construction dates back to 1915. The building has a twin in the form of the Chaki Agricultural College, also built according to the design of A.I. Dietrich.

In the late XIX - early XX centuries civil construction in Novocherkassk continued. Among the bright original buildings of the rational eclecticism of the "masonry" style, it is possible to note the teachers' seminary, erected in 1900, and the private real school of A.I. Kuznetsov, opened in 1905.

The corner of the two-story red-brick unplastered building of the teachers' seminary (architect V.N. Kulikov) of a complex L-shaped plan configuration with an attic floor and a multi-pitched roof was beveled, had an arcuate attic protruding above the roof with a roundshaped dormer, a hinged balcony above the protruding part of the porch of the central entrance. The building walls are rusticated with brick relief on the first level, the elongated windows had a circular end on the second level and are decorated with cornice. The planning structure of the building is of a corridor type, the mixed structural system has longitudinal and transverse load-bearing walls. The school is an example of the rational brick eclecticism of the neo-Renaissance [6].

The two-storey building of a real school of red brick on Atamanskaya Street was built (architect V.I. Zuev) in the Art Nouveau style [7]. With the traditional classical composition, its protruding central corner had a smooth curvature and walls decorated with floral ornaments and profiled belts. Very tall and narrow window openings are elongated, have arched ends of the first level and floral decorations at the end of the second. The roof of the building, which was later lost, had a complex curved shape with a bell-shaped dome in the central part and was also a reflection of the Art Nouveau style.

Interesting from the point of view of the new stylistic trend influence, which continues the neo-Gothic traditions in a more restrained style, is the building in which before the revolution the headquarters of the "Don Cossack" artillery was located, built in the mean, restrained forms of northern modernity [8].

In Novocherkassk at the beginning of the XX century, there were many civil buildings of public use: banking institutions, hotels, hospitals and clinics. Among them, it should be noted the architecture of the building of the Russian-Asian Bank (architect S.I. Boldyrev), in the architectural appearance of which a subtle combination of the classicism techniques with the elements of modernism is used. The building is a true decoration in the central part of the city [9].

\section{Conclusion}

The architectural palette of civil public buildings in Novocherkassk, most of which are built in the "masonry" style, is very diverse. In its rich complex combinations, there are elements of various directions of Russian eclecticism of the late XIX - early XIX centuries, starting from classicism and neo-Russian style, combined with Empire and Romano-Renaissance reminiscences, which received further development, which was original for the southern city in the elements of neo-Gothic and northern modernity [10,11].

\section{References}

1. Pre-revolutionary history of Novocherkassk. novocherkassk-gorod.ru

2. V.I. Kuleshov, In the lower reaches of the Don ("Art", Moscow, 1987)

3. E.I. Kirsanov, Ataman temple (History of the Holy Alexander Nevsky Church in Novocherkassk, 2008)

4. Diocesan School for Maiden. novocherkassk.net 
5. V.V. Nozdrev, Novocherkassk Suvorov military school, Historical review, 2013

6. Novocherkassk, Brief encyclopedia ("Novoprint", 2001)

7. Private real school of Kuznetsov. rutraveller.ru

8. The building that housed the artillery headquarters. kartarf.ru

9. Building of the Russian-Asian Bank. ok.ru>rostovosti/topic/64973985150315

10. E.I. Kirsanov, Glory and tragedy of Novocherkassk. 1805-2005. History of the Cossack capital. Volume 1. ISBN: 5-98990-001-5. 2005

11. E.I. Kirsanov, Glory and tragedy of Novocherkassk. 1805-2005. Historical sketches. Volume 2. ISBN: 5-98990-003-1. 2005 